\title{
"I Die, I Take It, For Maintaining the Fifth \\ Commandment": Patriarchy and the Last Dying Speeches of Royalists and Regicides
}

Sara Siona Régnier-McKellar, University of Victoria

\begin{abstract}
In January 1649, King Charles I was tried and found guilty of high treason and condemned to be "put to death, by the severing of his Head from his Body."1 At ten in the morning on the day of his execution he was accompanied to the scaffold by a regiment on foot, "colours flying, drums beating." 2 After having addressed the crowd in an uncharacteristically eloquent manner the King lifted his eyes and hands towards the sky, placed his head on the executioner's block and gave the sign that he was ready to die. With one swift blow the executioner decapitated the King and held up his head for the crowd to see. Philip Henry, then a boy of seventeen, remembered that there came from the crowd "such a groan as I never heard before, and desire I may never hear again."3
\end{abstract}

\footnotetext{
1 Thomas Bayly Howell, William Cobbett and David Jardine, A Complete Collection of State Trials and Proceedings for High Treason and Other Crimes and Misdemeanors: From the Earliest Period to the Year1783, with Notes and Other, (London, 1816), Vol. IV, 1128

${ }^{2}$ King Charles his Speech made upon the Scaffold (London, 1649), 3.

3 C.V. Wedgwood, The Trial of Charles I (London, 1967), 219. 


\section{Introduction}

My essay explores the ways the language of patriarchy functioned in the last dying speeches of royalists and regicides. The patriarchal model invoked by these camps differed greatly. Religion and political philosophy will be used to decipher the meanings that the private, public and divine patriarchal models held for royalists and regicides respectively.

For his supporters, the King's death meant not only the loss of an anointed monarch but also the loss of "our gracious King, the Husband of the Kingdom, the Father of his Subjects." ${ }^{4}$ Nevertheless, this crime fell short of the presumed villainy of the regicides and it was rumoured that their next design was to take "the very bodies of Men, women, and Children, whole Families taken prisoners for sale" and "if another War followed, they will spare neither Man, Woman, nor Child." 5 Regicides were accused of plotting the death of England's political and private families.

Recent works have stressed the plurality that existed within each Civil War faction. In his study on royalist identities, Jerome de Groot argues that the term 'royalism' signifies an "amorphous collection of attitudes."6 The royalists discussed in this chapter are peculiar in that they demonstrated their political allegiance via public execution. Similarly, parliamentarians cannot be described

\footnotetext{
4 John Gauden, Cromwells bloody slaughterhouse (London, 1660), 17.

5 The Last Damnable Designe of Cromwell and Ireton (London, 1649), 1.

${ }^{6}$ Jerome de Groot, Royalist Identities (New York, 2004), 2 
as a uniform group and the regicides represent an extremist element within this camp as the prosecution and execution of Charles I was highly contentious amongst parliamentarians. The regicides were charged with and executed for the ill-defined crime of "being instrumental in taking away the precious life of our late soveraigne Lord Charles the first of glorious memory." 7 The regicides discussed in this paper were the ten men executed as the result of the 1660 trials that followed the restoration of the monarchy. Of these men, six - Thomas Harrison, Adrian Scroop, John Jones, John Carew, Gregory Clement and Thomas Scot - were members of the high court and signed the King's death warrant. At their trial, they refused to express any feelings of remorse for their actions. Another four - Hugh Peters, Francis Hacker, John Cook and Daniel Axtell - were not directly involved in the King's trial, but their actions were deemed to have contributed to his sentencing.

\section{Patriarchy}

In 1657, Edmund Calamy explained that magistrates and ministers had little power to curtail sin when it was encouraged, or at least not reproved, in the household. The reformation of society must, therefore, begin within the family, which was the first and surest safeguard against

\footnotetext{
${ }^{7}$ Quoted in Howard Nenner, 'Regicides (act. 1649)', Oxford Dictionary of National Biography, (Oxford, 2004)

[http://www.oxforddnb.com.ezproxy.library.uvic.ca/view/article/70599, accessed 10 May 2009] 
unrighteousness. Calamy exhorted "governours of families" to be more conscientious and to "Catechize your children and servants; instruct them in the fundamentals of religion; would you keep them from error in the Head, from loosness in the life." It was the patriarch's responsibility to instil religion and godliness on his dependents and to protect them from their own potential villainy. Conversely, it was the duty of dependents to honour their office by obeying their Husband, Father or Master. Proper household government was prescribed as the remedy to society's maladies.

Calamy's instructions to the citizens of London are relevant, in that they represent early modern views on the household, often referred to as a microcosm emblematic of the social and political order. Robert Cleaver and John Dod compared the household to "a little Commonwealth" and argued that "by the good gouernment whereof, Gods glorie may be advanced." Similarly William Gouge believed that "a family is a little Church, and a little Commonwealth, at least a lively representation thereof, whereby tryall may be made of such as are fit for any place of authority, or of subjection in Church and Commonwealth."10 Thus, a clear parallel existed between the domestic and the social and political orders. It was within the family that individuals determined, practised and perfected their particular public callings and Christian duties. In 1653, Robert Abbot argued

\footnotetext{
8 Calamy, A Serious Advice to Citizens, (12th page, 14th page)

9 Robert Cleaver and John Dod, A godlie forme of householde government (London, 1612), 13.

10 William Gouge, Of Domesticall Duties (London, 1634), 17. 
that "the first government that ever was in this was in a Family." The family was the embryo of civil society and the mainstay of patriarchal authority. Abbot continued by claiming that "if families had been better, Churches and commonwealths all along had prospered." 11 A properly governed family repelled anarchy and formed the basis of an orderly Christian society.

But, during the British Civil Wars, society could be described as anything but orderly. England, Scotland and Ireland were thrown into chaos as armies marched across these countries, plundering, vandalising property and spreading the plague along the way. It is estimated that a larger percentage of the population died during the Civil Wars than in the First World War. ${ }^{12}$ Amidst the chaos of the Civil Wars, the family became a symbol of order and all camps - royalists, parliamentarians and covenanters - used patriarchy as a language of legitimation. Civil War factions simply could not dispense with invoking a patriarchal mandate. Christopher Durston argues that the family "formed the basis of the social structure of western Europe throughout the last millennium." 13 Theories on familial structure were firmly anchored in ideas on religion and natural order and patriarchal authority was, therefore, sanctified and venerated. The idea that fatherly authority was natural and must be obeyed was readily embraced by even some of the most radical members of early modern

${ }^{11}$ Robert Abbot, A Christian Family Builded by God (London 1653), sig. A4.

12 Michael Braddick, God's Fury, England's Fire : A New History of the English Civil Wars (London, 2008), xxii

13 Christopher Durston, The Family in the English Revolution (Oxford, 1989), 1. 
English society. ${ }^{14}$ All Civil War factions argued that they were defending the kingdom against an enemy that, in its savagery, failed to recognise sacred familial bonds. Thus, they portrayed themselves as the defenders of the kingdom's familial fabric; and, since families were commonly understood as the root of civil society, they were by extension portraying themselves as the defenders of a natural and divinely ordained order.

The task of defending patriarchy was inherent to the defence of a conservative societal structure and was a testament to that which is immemorial - not born of human tradition but divinely sanctioned. According to Gordon J. Schochet, the viability of patriarchal theory in seventeenthcentury Britain was assured by the post-Reformation 'genetic method' which favoured anti-innovation and was based on the belief that 'the only viable standard and source of all political values is the beginning of the political order." 15 Therefore, at its simplest, seventeenth-century patriarchy can be defined as an unprogressive model of authority and subordination; such a model was applied to the individual household as well as to the political structure. Indeed, the patriarchal order that each camp

\footnotetext{
${ }^{14}$ A the height of the Putney Debates, Leveller Maximilian Petty admitted that "servants and apprentices

[...] are included in their masters"; quoted in J.P. Sommerville, Roylalists and Patriots: Politics and Ideology in England, 1603-1640 (New York, 1999), p.31. 15 Gordon J. Schochet, Patriarchalism in Political Thought: The Authoritarian Family and Political Speculation and Attitudes Especially in Seventeenth-Century England (Bristol, 1975), 58; For example, in his speech concluding his defence, the earl of Strafford said "Let us rest content with what our fathers left us;" England's black tribunall set forth in the triall of K. Charles I at a High Court of Justice at Westminster-Hall (London,1660), 51. 
fought to preserve consisted both of a model of domestic and social order and a political theory on governance.

Since the spread of gender and women's history in the 1970 s, the study of patriarchy has gained currency. ${ }^{16}$ But, being born of this specialised historical field, patriarchy was, for a long time, defined solely in gendered terms. As late as 1992, Patricia Crawford described a patriarchal society as one in which "fathers and men had social advantages." 17 Domestic patriarchy was characterised by three household power relations: husbands and wives, parents and children and masters and servants. Recognising the multivalent power exercised within the household and within society, historians have recently revisited the definition of patriarchy and have expanded it beyond the male-female binary model. In Meanings of Manhood in Early Modern England, Alexandra Shepard argues that not all early modern men had the same gender and that historians have been mistaken in equating manhood and patriarchy. She claims that "while there is no doubt that males were the primary beneficiaries of this [patriarchal] model, women were not wholly or unilaterally

16 See for example, Lawrence Stone, The Family, Sex and Marriage in England 1500-1700 (London, 1977); Susan Dwyer Amussen, An ordered society : gender and class in early modern England (Oxford, 1988) ; Anthony Fletcher, Gender, Sex and Subordination in England, 1500-1800 (New Haven, 1995); Laura Gowing Domestic dangers : women, words and sex in early modern London (Oxford, 1996) ; Sara Mendelson and Patricia Crawford, Women in Early Modern England, 1550-1720 (Oxford, 1998); Bernard Stuart Capp When gossips meet : women, family and neighbourhood in early modern England (Oxford, 2003). 17 Patricia Crawford, "The Challenge to Patriarchalism: How did the Revolution affect Women?" in Revolution and Restoration England in the 1650s by John Morrill (ed) (London, 1992), 112. Five years later, in 1998, Crawford again defined patriarchy as "a political system based on the dominion of a husband and father over his household;" Patrician Crawford and Sara Mendelson, Women in Early Modern England, 6 
subordinate by it, and men's gains were by no means uniform."18 Patriarchy was defined as a specific phase in the life of men. It was the 'constant age' by which time men had shed the pride and impetuousness of youth but had not yet fallen victim to the physical and mental decay of old age. ${ }^{19}$ It was at this stage of their life that men were most likely to achieve self-command. But, patriarchy further depended on economic independence and social and political authority. Linda Pollock recognises that "the consensus of recent scholarship is that masculinity was more of a burden, its power weaker than previously thought."20

David Underdown asserts that patriarchal theories on governance stemmed from the already existing social patriarchal model, stating that "patriarchal authority within the family was the cornerstone of Elizabethan and Jacobean political theory, the ultimate 'natural' justification for obedience to the state: to reject either was to threaten the entire social and political order." 21 Similarly, J. P. Sommerville is sensitive to the interconnectedness of the two patriarchal models, and claims that, "the strength of patriarchalist political theory lay in its appeal to the common social assumptions of contemporaries." 22

\footnotetext{
18 Alexandra Shepard, Meaning of Manhood in Early Modern England (Oxford, 2003), 3

${ }^{19}$ Shepard, Meaning of Manhood in Early Modern England, 21-46

20 Linda Pollock, "Rethinking Patriarchy and the family in seventeenth-century England" in Journal of Family History (1998) 23:1, 21.

21 David Underdown "The Taming of the Scold: the Enforcement of Patriarchal Authority in Early Modern England" in A. Fletcher and J. Stevenson (eds), Order and Disorder in Early Modern England (Cambridge, 1985), 117.

22 Sommerville, Roylalists and Patriots, 29.
} 
Patriarchy was, therefore, an overarching structure. In defending their cause, all Civil War factions argued that they were defending a divinely ordained political patriarchal order. Royalists believed that God had vested absolute authority in the monarch, the kingdom's political father, and that patriarchy was therefore, best defended by obedience to the King. Conversely, parliamentarians defined the patriarchal order in purely divine terms, viewing God as their Father and Master and endeavouring to become his instruments by purging the kingdom of false religion. Among parliamentarians, regicides came to believe that this was best achieved by eliminating the King, the source of God's wrath.

\section{Dying Well}

During the Civil Wars, the supporters of royalists and regicides developed a distinctive discourse that testified to the justice of their cause and the falsehood of that of their enemies.' One of the mediums available for the articulation of these discourses was public execution. Lake and Questier argue that public executions and last dying speeches should be viewed as "dialectic between several competitive ideologies." 23 Both Catholics and Protestants used public executions to challenge the social order. Hence, the discourse of martyrdom was open to appropriation and

23 Peter Lake and Michael Questier “Agency, Appropriation and Rhetoric under the Gallows: Puritans, Romanists and the State in Early Modern England" in Past and Present, No. 153 (Nov., 1996), 65. For a competing view see J. A. Sharpe “'Last Dying Speeches': Religion, Ideology and Public Execution in Seventeenth-Century in England" in Past and Present, No. 107 (May, 1985). 
dispute by various groups. Freeman similarly argues that the scaffold was the site of multivalent power. ${ }^{24}$ Public executions and execution pamphlets, then, played an important role in reinforcing and spreading social values.

Thomas S. Freeman argues that, despite being executed for political reasons, Charles I and the regicides "successfully wore the mantle of Christ" at their execution. ${ }^{25}$ By the end of the sixteenth century, the Christocentric model of martyrdom had became England's predominant model. ${ }^{26}$ At their executions, the condemned consciously tried to imitate the Passion of Christ because "the closer the similarity between the details of the death of Christ and the details of the death of the martyr, the more difficult it was to dismiss the martyr as a criminal or a heretic." 27 The supporters of royalists and regicides, therefore, exploited the similarities between the degradation of the condemned and the humiliation inflicted upon Christ to bestow upon their allies the mantle of martyrdom.

According to Andrea McKenzie, the late seventeenth-century crowd who came to witness the

24 Thomas S. Freeman “'Imitatio Christi with a Vengeance': The Politicisation of Martyrdom in Early-Modern England" in Martyrs and Martyrdom in England, $c$. 1400-1700 by Thomas S. Freeman and Thomas F. Mayer (eds) (Rochester, 2007), 55. See also, Andrea McKenzie. “Author's Response of James Sharpe review of Tyburn's Martyrs: Execution in England 1675-1775, Andrea McKenzie" (review no. 677), online (www.history.ac.uk/reviews/ paper/ sharperesp.html). Date posted: July 2008

25 Freeman "Imitatio Christi with a Vengeance," 62.

26 For a discussion of earlier models of martyrdom see Danna Piroyansky “ 'Thus may a man be a martyr': The Notion, Language and Experiences of Martyrdom in Late-Medieval England" in Martyrs and Martyrdom in England, $c$. 1400-1700 by Thomas S. Freeman and Thomas F. Mayer (eds) (Rochester, 2007), 70-87.

27 Freeman "Imitatio Christi with a Vengeance", 39. 
executions of ordinary criminals was largely composed of members of the lower orders. However, the public for printed accounts of these executions was primarily from the middling sorts. ${ }^{28}$ Therefore, it can be assumed that the messages promulgated by the condemned reached a large and socially heterogeneous audience. McKenzie further argues that the size of the audience made undetected forgeries of the last dying speech and comportment of the condemned a high unlikelihood. The accounts, however, were not identical as they "were, by definition, partisan and scripted documents, mediated by the conventions of the genre and the expectations of their audience." 29 The authors of execution pamphlets exploited these conventions to glorify or vilify the condemned.

\section{Royalists, Martyrdom and the Political Father}

In early modern England, "charity" was understood as a state of Christian love and harmony. Jesus commanded that: "Thou shalt love the Lord thy God with all thy heart, and with all thy soul, and with all thy mind. This it the first great commandment. And the second is like unto it, Thou shalt love thy neighbour as thyself" (Matt 22: 37-39). ${ }^{30}$ All

28 Andrea McKenzie, Tyburn's Martyrs : Executions in England 1675-1775 (London, 2007), 26.

${ }^{29}$ McKenzie, Tyburn's Martyrs, 46.

30 "charity, 1.b." The Oxford English Dictionary, 2nd ed. 1989, OED Online, Oxford University Press. (April 12th 2009). According to Keith Wrightson, during the early modern period 'charity' was reinterpreted in the context of the politics of subordination. The definition of 'charity' evolved from describing a state of Christian harmony to describing an act of kindness towards the poor; Keith Wrightson "The Politics of the Parish in Early Modern England" in The Experience of Authority in Early Modern England by Paul Griffiths, Adam Fox 
royalists were faithful to this divine commandment and were careful to die in a state of Christian harmony. They forgave 'all the world', including the authors of their death, before their execution. ${ }^{31}$ Royalists were also careful to instruct their families to be charitable and forgive those responsible for their deaths. The Earl of Strafford told his son "to bear no private grudge, or revenge toward any man concerning me," while Lord Capel commanded his son "never to revenge his death, though it should be in his power, the like he said unto his wife." 32 Similarly, Charles I had, on many occasions, charged Bishop Juxon to instil in his eldest son forgiveness. ${ }^{33}$

Not only was charity central to royalists' dying speeches, it was also used to characterise their lives. The King exhibited great charity during his trial. Once his sentence had been read, he was escorted out of the courtroom; it was reported that, "as he passed down the stairs, the insolent Soldiers scoffed at him, casting the smoke of their tobacco...in his face...and one more insolent than the rest, spitting in his face." 34 The comparison with Christ was none too subtle (but conformed to the Christocentric model of martyrdom). Like Jesus, who had withstood the abuse of soldiers "who spit on him, and took

and Steve Hindle (eds.) (New York, 1996), 33. See also John Bossy Christianity in the West (Oxford, 1985)168-69.

31 See Howell, A Complete Collection of State Trials, Vol. III, 1517, 1522

(Strafford) ; Howell, A Complete Collection of State Trials, Vol. IV, 601 (Laud), 1138 (Charles I), 1190 (Hamilton), 1193 (Holland), 1239-1240 (Capel).

32 Howell, A Complete Collection of State Trials, Vol. III, 1523; Howell, A Complete Collection of State Trials, Vol. IV, 1231.

${ }^{33}$ Howell, A Complete Collection of State Trials, Vol. IV, 1140.

34Ibid., 1130. 
the reed, and smote him on the head" (Mathew 27:30), King Charles I reacted calmly and with great charity, forgiving the soldiers who "for a piece of Money [...] would do so for their commanders." 35 James, the Duke of Hamilton, one of the King's greatest Scottish allies, was also described as charitable. Gilbert Burnet, who wrote a biography of Hamilton, described an altercation that took place between the Duke and a zealous woman who threw a rock at him. When it was ordered that her hand should be cut off, Hamilton "procured her Pardon, and said, The Stone has missed him, therefore he was to take care that their Sentence might miss her." 36 These stories were used to show the royalists' charity - their ability to live harmoniously with others.

The King's charity was understood by his supporters as an indication of his ability to rule. Political patriarchal theorists argued that God had vested absolute authority in the earliest patriarchs who had also been the first rulers. Robert Filmer's Patriarcha is considered to be the highest and most complete expression of political patriarchal theory. ${ }^{37}$ In this work, Filmer links familial origins to political obligation. He argues that both paternal and regal authority were born simultaneously in Adam who governed by right of fatherhood over his wife and children. This authority was inherited, since "not only Adam but the succeeding patriarchs had [...] royal authority over their

35 Howell, Ibid., 1130.

36 Gilbert Burnet, The memoires of the lives and actions of James and William, Dukes of Hamilton and Castleherald, (London, 1677), 413.

37 Schochet Patriarchalism in political thought, 1. 
children." ${ }^{38}$ After the flood the rule of patriarchs continued uninterrupted beginning with Noah and his three sons. These patriarchs possessed authority not just because of their fatherhood but because they enjoyed a contract - a covenant - with God. God tells Noah that "I establish my covenant with you, and with your seed after you." (Gen 9:9) The patriarchs' power, then, was natural and divinely |әзь sanctioned. ${ }^{39}$

Henry Ferne believed that patriarchal rule began with Noah, rather than with Adam, but nonetheless argued that regal power was rooted in paternal power as the authority to govern appeared first "through the veine of nature in a paternal or Fatherly rule." 40 He claimed that the earth was divided between Noah and his three sons; and, as their families grew, their progeny were assigned new territories and spread across the face of the earth. Colonies were simultaneously families and kingdoms. Dudley Diggs, who also believed that "Regall power sprang first from Paternall," 41 characterised paternal rule as stable and

\footnotetext{
38 Robert Filmer, "Patriarcha The Naturall Power of Kings Defended Against the Unnatural Liberty of the People" in Sir Robert Filmer Patriarcha and Other Writings by Johann P. Sommerville (ed) (Cambrdige, 1991), 6-7.

39 Divine power and natural law were not mutually exclusive in early modern thought. For example the royalist author of Christus dei argued that "God is the sole cause and author" of the Law and Nature; Christus dei (Oxford, 1642), 6. Similarly George Buchanan, a contract theorist, defined nature as "That LIGHT infused by God into our Minds..this Light some call Nature, others the Law of Nature..."; Buchanan, George, De jure regni apud Scotos (1680), 12-13.

40 Henry Ferne, Conscience Satisfied (Oxford, 1643), 8.

41 Dudley Diggs An answer to a printed book intituled, Observations vpon some of His Majesties late answers and expresses. (London, 1642), 5. In a later work, Diggs claimed that while "paternall authority was regall" no modern King could claim that this was the basis of his authority. See Diggs The vnlavvfulnesse of subjects taking up armes against their soveraigne (Oxford, 1643), 15. 
orderly. God, who "digested one chaos into order," gave regal power to Adam so that he would not live in a state of confusion. ${ }^{42}$ John Spelman claimed that 'natural kingdoms' were ones in which Parents ruled over "their children, children's children, and servants." 43 Significantly, 'natural kingdoms' were the dialectic opposite of 'violent kingdoms.' This imagined parcelling of kingdoms implied that natural kingdoms were not only natural - as their names clearly implies - but were also stable and secure, free from violence. Spelman contended that the King was the head of the body politic "so if you destroy the head or kingly power, you destroy the kingdome, and dissolve it into Chaos of confused multitude." 44 Like Diggs and Ferne, Spelman saw in the defence of the King's sovereignty the best way of ensuring stability. The King's rule was ordained by God and was the most natural form of sovereignty since "Domestical government is the very Image and model of Sovereignty in a Common-weale." 45

The assumed congruity between domestic and political patriarchy led to the publication of an abundance of printed material idealising the King's family life. His ability to successfully govern his household was offered as proof of his ability to govern his kingdom. Charles, himself, equated his capacity for fatherly affection to an ability to rule. In a letter to his eldest son, dated November 29th

\footnotetext{
42 Dudley Diggs An answer to a printed book, 4.

43 John Spelman, Certain Considerations upon the duties both Prince and People (Oxford, 1642), 2.

44 John Spelman, $A$ view of a printed book intituled Observations upon His

Majesties late answers and expresses (Oxford,1642), 8.

45 Spelman, $A$ view of a printed book, 9. 
1648, the King expressed both his paternal affection for his son and for his subjects: "You are the Son of Our love...We do not more affectionately pray for you (to whom we are natural Parent) then We doe [...] that all our Subjects (to whom we are a Politick Parent) may have such sober thoughts as to seek their Peace." 46 He further tells his son that if he uses his power wisely he "will never want means to be a Father to all." 47 Charles believed that for a ruler to be politically successful he must also be a good father.

The King's supporters was especially commended him for his relationship to his wife. Clarendon wrote that, "he was so great an example of Conjugal Affection, that they who did not imitate him in that particular durst not brag of their liberty." 48 Eikon Basilike, published in 1649, and purported to be King Charles I's testimony, greatly contributed to Charles' image as a good husband. While the work was almost certainly not written by Charles, but by John Gauden, it was nonetheless authorised and probably closely overseen by the King. ${ }^{49}$ As such, it is an ideal source to explore the ways in which the King and the King's supporters were portraying him and defending his rule. A whole chapter of the work is devoted to the Queen's departure from England. A whole chapter of the work is devoted to the Queen's departure from England. The love

${ }^{46}$ England's black tribunall set forth in the triall of K. Charles I at a High Court of Justice at Westminster-Hall (London,1660), 43.

47 England's black tribunall, 42.

48 Clarendon, Edward Hyde, Earl of Memoirs of Kings Charles I and the loyalists who suffered in his cause; chiefly extracted from Lord Clarendon's History of the rebellion (London, 1795), 4

${ }^{49}$ For a more extensive discussion of the Eikon Basilike see Andrew Lacey, The Cult of King Charles the Martyr, (Rochester, 2003), esp 77-87. 
and happiness that is shared by Charles and Henrietta Maria is explicitly expressed: "Her sympathie with Me in my afflictions, will make her vertue shine with greater lustre, as starrs in the darkest nights; and assure the envious world, that she loves me, not my fortunes." 50 Shortly before his execution, Charles asked his daughter, Elizabeth, to tell his wife that "his thoughts never strayed from her, and that his love should be the same to the last." 51 This further attests to the conjugal affections shared by the royal couple. It also shows that Charles' children were witness to this love and, in a sense, participated in it.

Charles I was also portrayed as a good father. His last meeting with his youngest son, Henry, and his daughter, Elizabeth, is related in a way that conveys a sense of domestic happiness. He addresses both his children as 'sweetheart' and takes his son upon his knee, demonstrating the affection he holds for him. Elizabeth makes show of her love for her father when she pours "forth abundance of Tears" at the thought of his impending death. ${ }^{52}$ Charles, in this last meeting, is concerned for his children's future safety. He instructs his youngest son to refuse the crown even if it is offered to him, for if he does "they will cut off your Brothers heads...and cut off thy head too at the last." 53 His depiction as, "virtuous, chaste, pious, a good father, husband and master," made him an "example

${ }^{50}$ Eikon Basilike : The Pourtrature of His Sacred Majestie (London, 1649), 43-44.

51 Ibid., 282.

52 Ibid., .280.

53 Ibid., 280-81. 
of holy living" and reinforced the idea of him as Christlike. ${ }^{54}$

Inspired by the Christocentric model of martyrdom, other royalists were also depicted as having maintained a state of Christian love and charity in their households. Furthermore, as military leaders of the royalist army, they too commanded obedience and their family life similarly demonstrated their capacity to rule. James, the Duke of Hamilton, was portrayed as a loving husband and father. His relationship with his wife is said to have started in a less than ideal way when he was fourteen and she seven, but "her excellent qualities did afterwards overcome that Aversion into as much Affection as he was capable." 55 The Hamiltons' matrimonial relationship was described as one that epitomised the ideals of the time. Hamilton's character and behaviour as a husband ensured his wife's continued love and obedience. "She was a most affectionate and dutiful wife [...] she had the greatest reason to bless God, for having given her such a Husband, whom as she loved perfectly, so she was not ashamed to obey." 56 As Alexandra Sheppard has argued, "the self-government expected of manhood was the basic of men's claims to authority." 57 Hamilton's capacity to so perfectly govern his household

54 Andrew Lacey, " 'Charles the First, and Christ the Second': The Creation of a Political Martyr" in Martyrs and Martyrdom in England, c. 1400-1700 by Thomas S. Freeman and Thomas F. Mayer (eds) (Rochester, 2007), 208. According to Andrew Lacey, the King's cult of martyrdom began being formed in 1645, years before his execution.

55 Burnet, The memoires of the lives and actions of James and William, Dukes of Hamilton, 406.

56 Burnet, Ibid., 407.

57 Alexandra Shepard, Meanings of manhood in early modern England (Oxford, 2003), 70. 
implied that he was a patriarch who could also govern himself and was fit to command.

Lord Capel's parting with his friends and family, and especially with his wife, is also indicative of the way royalists and their families were depicted as living in a state of Christian love. These farewells were described as the "saddest spectacle that could be." On this occasion "he [Capel] could not choose but shew and confess a little human frailty, yet even then, he did not forget both to comfort and councel."58 Once, his family and friends had left him he turned to the minister who was attending him and said "the hardest part of my work in this world is now past."59

Royalists also showed concern for the prosperity of their families after their deaths. The Duke of Hamilton asked his brother to "be a Father to my poor Children, and that they be not forced to marry against their will." 60 This indicates Hamilton's will to have someone take over his responsibilities as patriarch after his death. This was a common theme amongst executed royalists and the Earl of Strafford advised his wife to take another husband, stating "I speake, God knows, not to disswade you from marrying, againe, for that will be the best for you, both in respect of God, and of the world." 61 The condemned royalists were seeking earthly replacements to help their families after

\footnotetext{
58 Howell, A Complete Collection of State Trials, Vol. IV, 1231

${ }^{59}$ Ibid.,

60 Burnet, The memoires of the lives and actions of James and William, Dukes of Hamilton, 397.

61 Thomas Wentworth, Earl of Strafford, A letter sent from the Earle of Strafford to his Lady in Ireland a little before his death May 11. 1641. (London,1641.), 3. 
their deaths. Royalists' concern for their families can be seen as an imitation of Christ's concern for his mother while on the cross (John 19: 26-27). However, as we will see, the royalists expressed their concern for their families' wellbeing using language significantly different from that of the regicides.

Seventeenth-century conduct literature claimed that love was man's primary marital duty. ${ }^{62}$ Alexandra Shepard has observed that while conduct books "sought to maintain men's authority over women, [they] paradoxically emphasized that their position of dominance was best achieved without dominance." 63 A patriarch ensured the obedience of his dependents - his wife, children and servants - by his gentleness of character. The royalists' capacity to successfully (and lovingly) exercise authority over their household was taken as proof of their ability to govern. Most notably, the supporters of the King used his family life to reinforce his image of a caring political patriarch and justify obedience to him. Lord Clarendon described Charles as "the worthiest Gentelman, the best Master, the best Friend, the best Husband, the best Father, and the best Christian that the age in which we liv'd produc'd." 64 The attributes used to describe him simultaneously conveyed the idea of a Christ-like character and of a man capable of exercising civic and domestic sovereignty.

62 See, for example, Thomas Hardy Love and Fear: The inseperable Twins of Blest Matrimony (London, 1653); Thomas William Christian and Conjugal Counsell (London, 1661)

63 Shepard, Meanings of manhood, 82. See also Capp, When Gossips Meet, 31-32.

64 Clarendon, Memoirs of Kings Charles I, 6. 
The political patriarchal model described by royalists at their execution was also informed by ideas on charity and domestic household governance. Royalists believed that the kingdom's sufferings were caused by "the sins of the nation, which manifested themselves in faction and resistance towards an anointed monarch."65 Therefore, defending the King's cause was, by extension, a defence of God's will and the surest way of appeasing his anger and restoring a state of Christian harmony. On the scaffold, King Charles himself described his execution as a "great sin" and desired that his executioners "take the right way to the peace of the Kingdom: for my charity commands me not only to forgive particular men, but my charity commands me to endeavour to the last gasp the peace of the Kingdom." 66 Before his execution, Capel addressed the crowd, stating: "I die, I take it, for maintaining the fifth commandment, enjoin'd by God himself, which enjoins Reverence and Obedience to Parents." ${ }^{67}$ Like Capel, other royalists, expressed the belief that they were dying for their loyalty to England's political patriarch - the divinely ordained Charles I. The Earl of Strafford instructed his son that if the King requested his service, "he should carefully undertake it, to testify his obedience, and withal to be faithful and sincere to his Master, though he should come to

65 Lacey, "Charles the First, and Christ the Second", 208.

${ }^{66}$ King Charles his Speech made upon the Scaffold, 5.

67 The several speeches of Duke Hamilton Earl of Cambridg, Henry Earl of

Holland, and Arthur Lord Capel, upon the scaffold immediately before their execution, on Friday the 9 of March (London,1649), 38

Past Imperfect

15 [2009] | @ | ISSN 1711-053X | elSSN 1718-4487 
the same end that himself did." 68 John Morris, in his dying speech declared:

If I had a thousand lives I would willingly lay them down for the cause of my King, the Lord Anointed: the Scripture commands us to fear God and honour the King, too be subjects to every ordinance of man for the Lords sake, whether to the king as supreme, or to those that are in authority under him." 69

The King was a father and a master; he was the 'Lord Anointed'. The executed royalists maintained their loyalty to the King right to the moment of death - their death itself was a powerful reminder of their loyalty to his person and to his cause.

John Spelman claimed that all subjects owed reverence to the King. He admitted that King's could be tyrannical. In such instances, subjects should not "invade Gods peculiar right" by attempting to depose of the King, but rather should work towards their own reformation and pray for the King's. ${ }^{70}$ A tyrannical King was a test from God and to resist his divinely ordained ruler was to "antevert the glory that God seemed to seeke in our trial." 71 But Charles' family life proved him to be a loving patriarch and not tyrannical ruler that the rebels made him out to be.

${ }^{68}$ England's black tribunal, 57-58.

69 Ibid., 122-123.

70 Spelman, Certain Considerations, 10.

71 Ibid., 18. 


\section{Regicides, martyrdom and the Divine Father}

While Charles' supporters portrayed him as a good patriarch, his enemies tried to undo this powerful image. In 1646, Parliament (not yet controlled by those who would become regicides) by published a pamphlet entitled The Kings Cabinet Opened, a selection of Charles I's personal correspondence captured from the King's coach when royalist forces broke rank at the Battle of Naseby. In this pamphlet, Henrietta-Maria was portrayed as a domineering wife. She exercised authority over her husband and held undue influence in matters of state. This was evidenced, according to the editors of the pamphlet, by a letter written by Charles in May 1645. In this letter, the King told his wife that his eldest son (the future Charles II) had asked him to swear in Sir John Greenfield as Gentleman of his Bedchamber. The King wrote to the Queen that he had "refused the admitting of him until I shall heare from thee."72 Thus, the King was portrayed as unable to make any decision, even on a seemingly unimportant matter, without first having consulted his wife. Therefore, the first conclusion the reader should draw from this personal correspondence was that "the Kings Councels are wholly managed by the Queen; though she be of the weaker sexe, born an Alian, bred up in a contrary Religion."73 The King's submission vis-à-vis his wife was proof of his inability to

72 The Kings cabinet opened: or, Certain packets of secret letters \& papers, written with the Kings own hand, and taken in his cabinet at Nasby-Field, June 14. 1645 (London, 1645), 11.

73 The Kings cabinet opened, 42. 
govern. Although it was not stated explicitly, conjugal love could, in this case, be interpreted as a threat. It was Charles' love for his wife that has induced him into submission.

After the King's execution, John Cook, solicitorgeneral for the Commonwealth, published his intended speech for the prosecution in which he tried to explain the problematic fact that there were no legal provisions for executing a King. He argued that the absence of laws concerning the matter did not prevent the action but rather pointed to its extraordinary nature. He stated that, "as in the Common instance of Paricide, The Romans made no Law against him that should kill his Father, Thinking no child would be so unnatural to be the death of him who was the Author of his life." 74 This analogy implied that Charles was guilty of attacking that which is the 'author of his life.' Cook, expanding on this motif, also accused Charles of participating in the poisoning of his father, the former King James VI \& I. Charles protected the Duke of Buckingham, his accomplice, from an inquest and in so doing demonstrated that he "hath no nature to do justice to his own Father."75 He was an unnatural son, usurping the natural authority of his father. Therefore, Cook asked his readers: "Was he [Charles I] fit to continue a Father of the people, who was without natural affection to his own Father?"76 To justify the King's execution, regicides used familiar analogies that would have resonated with their audience; by threatening

\footnotetext{
74 John Cook, King Charls his case: or, An appeal to all rational men, concerning his tryal at the High Court of Iustice (London, 1649), 25.

75 Cook, King Charls his case, 12.

76 Ibid., 
his biological and political families Charles was a menace to the kingdom's stability.

The parliamentarians' criticism of Charles reflects their concern with proper domestic order. While also concerned with household order, regicides, in preparing for death, focused on that which is eternal versus that which is temporal. ${ }^{77}$ They cast aside their families in order to concentrate on their forthcoming salvation. John Cook defined love as something that was aimed exclusively at God. "A husband, wife, child, friends, and all creaturecomforts are to be loved so far as we see God in them; so our affections and desires must not be fixed upon them, but terminate in God...our loves must only pass by the Creatures, and settle in God." 78 In jail, Hugh Peters, preached on the causes of despondency. He argued that by "over valuing our comforts, putting too much upon wife, children, estate or Life it self, a man is apt to be cast down when he thinks of parting with them."79 It was better not to get attached to earthly things, for these attachments detracted one from the glories of the afterlife. Furthermore, despondency was proof of a lack of faith. Therefore, to hold earthly goods in high esteem distracted a person from the

77 For an example of a regicides concern with proper household governance see Hugh Peters A dying fathers last legacy to an onely child (London, 1660), esp 4345. For a similar example concerning a Socttish Covenanter see Archibald Campbell Argyle Instrustions to a Son (London 1661), esp 1-28, 39-48

78 The speeches and prayers of some of the late King's judges (London, 1660), 5051

${ }^{79} \mathrm{~W}$. S. A compleat collection of the lives, speeches, private passages, letters and prayers of those persons lately executed viz. (London, 1661.), 114. For a recent study on the authorship of $A$ compleat collection see, Matthew T. Jenkinson "A New Author for the 'observation' in Rebels no Saints (1661)" in Notes and Queries (September 2005), 311-14. 
essence of worship and piety and could even be taken as a sign of reprobation. Similarly, while in jail, John Jones attempted to comfort a relation by advising him to "remove all Creature-Comforts from us, that our souls might have nor resting place to delight in." 80 Family and friends were depicted as potential obstacles in the regicide's final search for salvation and eternal happiness.

In their dying speeches, regicides were primarily concerned with salvation, "the saving of the soul; the deliverance from sin and its consequences, and admission to eternal bliss, wrought for man by the atonement of Christ." 81 They believed in the Calvinist doctrine of double predestination - that God exercised his prerogative in electing a select few for eternal salvation and others for reprobation. ${ }^{82}$ Atonement was limited, as Christ had only died to save the elect. In their final moments, regicides endeavoured to identify signs of their own election. Faith was what distinguished the elect from the rest of humanity; it was the gift of grace. However, predestination was understood differently amongst Protestants. Arminianism, said to have been embraced by some prominent royalists, most notably by King Charles I, rejected the Calvinist doctrine of limited atonement arguing instead that Christ has died for all, not just the elect. ${ }^{83}$ Furthermore, the

80 The speeches and prayers of some of the late King's judges, 76.

81 "salvation, 1.a." The Oxford English Dictionary, 2nd ed. 1989, OED Online. Oxford University Press. (April 12th 2009).

82 The doctrine of double predestination was imposed by the Westminster Assembly in 1647.

83 David R. Como argues that the 1630 s concern with predestination was climacteric to later debates on the nature of politics and governance. To

Arminians, the Calvinist doctrine of election was worrisome because it seduced

Past Imperfect

15 [2009] | (C) | ISSN 1711-053X | eISSN 1718-4487 
doctrine of election was accorded varying degrees of importance amongst Calvinists. For example, Peter Marshall has identified two types of Calvinist. The first type, 'experimental Calvinists', made predestination the 'centre of their piety' and continuously searched for signs of election. The second, 'creedal Calvinists', believed in predestination but since the identity of the elect was impossible to determine their preferred to avoid the topic. It was seen as socially disruptive as the search for proof of election could be divisive. ${ }^{84}$ Therefore, a more temperate approach to predestination also existed within Protestantism.

The regicides' approach to election was anything but temperate. They embraced the doctrine of total depravity that contended that the fallen man was, on his own, incapable of good and that salvation was, therefore, entirely dependent on God. By focusing on their own degeneracy the regicides were arguing for God's goodness. John Carew "much admired the Depths of love of God to such an unworthy Worme." 85 Thomas Harrison shared in this sentiment, saying "Oh what am I poor worm that I should be accounted worthy to suffer anything for the sake of my Lord and Saviour Jesus Christ." 86 A just God could

\footnotetext{
"Calvinist divines into assurance of their own elect status slid into a dangerous state of security, which absolved them from all moral obligations to God, king, and neighbour." ${ }^{3}$ So, not only did Arminians disagree with the Calvinist doctrine of predestination, they also believed that it engendered treachery. David R. Como 'Predestination and political conflict in Laud's London" in The Historical Journal 46:2 (2003), 272.

84 Peter Marshall, Reformation England, 1480-1642 (London, 2003), 129.

85 The speeches and prayers of some of the late King's judges, 14.

86 Ibid., 10.
} 
reasonably have condemned all men. But, God was merciful and with the blood of his only son, he saved the elect. John Carew, in his dying prayers, declared that "the most holy and righteous God, that had but one onely begotten sonne that was the delight of his soul and should take pleasure to bruise him that we might be healed." 87 It was the wickedness of man that made their salvation so merciful.

A preoccupation with sin was common among Christians. ${ }^{88}$ But, while regicides insisted on their own depravity they refused to admit any feelings of guilt. Their clear conscious was proof of the divinity of their cause. At his execution Thomas Harrison stated that "as to the bloud of the King, I have not in the least any Guilt lying upon me [...] the thing was more of God then of Men." 89 There was no reason to be troubled by his actions towards the King since God commanded them. Man was powerless to shape destiny and could only hope to be a passive instrument of God's providence. According to J.C. Davis "to deny God's control of political and military events was to risk not only rebuke or temporary anger but being cast permanently into outer darkness, bereft of hope." ${ }^{90}$ Unsurprisingly, then, absence of guilt also manifested itself in an unwillingness to repent. When a man came to visit Adrian Scrope in jail and

87 W. S. A compleat collection, 50.

${ }^{88}$ All royalists identified their execution as a divine punishment for their sins. Notably, the King was convinced that his execution was punishment for signing the earl of Strafford's death warrant. See, Howell, A Complete Collection of State Trials, 1138 and Eikon Basilike, 6-12.

${ }^{89}$ The speeches and prayers of some of the late King's judges, 2.

90 J.C. Davis "Living with the living God: radical religion and the English Revolution" in Religion in Revolutionary England by Christopher Durston and Judith Matlby (eds) (Manchester, 2006), 20. 
beseeched him to repent, Scrope "put forth his hand, and thrust him from him, using these words AVOID SATAN."91 Hugh Peters was approached by two Episcopalian clergymen who asked Peters to repent so that he may be pardoned by King Charles II. The clergymen were interpreted as trying to take advantage of Peters' fragile state. Despite his fragility "the Lord did help him bear up with much courage...and [he] told them that he had no cause in the least to repent of Adhering to that interest."92 Regicides equated repentance with a denial of their cause God's cause.

The regicides lack of penance can also be explained by their dismissal of the political patriarchal theory. They believed that a Covenant existed between the people and God and every person had the obligation of protecting the law and true religion; the King, having failed to do so, menaced the kingdom's safety. John Milton, who supported the lawfulness of the regicide, argued that it was the people, once assembled into civil societies that elected a King. He used Scripture to buttress this assertion reminding his reader that, while the Lord chose David to be the ruler of the Israelites, it was the elders of Israel who made a covenant with David and anointed him King. (2 Sam 5:3, I Chron 11:3). Furthermore, he evoked the story of Jehoash who was made King of Israel by a covenant that was made between "the Lord, and the king and the people, that they should be the Lord's people; between the King also and the people." (2 Kings, 11:17) Therefore, the King's power was

91 The speeches and prayers of some of the late King's judges, 74

92 The speeches and prayers of some of the late King's judges, 62 
granted both by God and the people. Monarchical authority was derivative, "committed to them [Kings] in trust from the people" and the people's right of "choosing, yea of changing thir own Government is by the grant of God himself in the People." ${ }^{93}$ Regicides, believed that King was at the source of the kingdom's woes; he was untrustworthy and unfit "to continue a Father of the people." 94

The court that tried Charles defended its authority by claiming that it lay in the "Commons of England, assembled in Parliament, in the behalf of the People of England." 95 Its aim was to defend the liberty and freedom of the English people. But, freedom was envisioned as passive obedience to an active God. Regicides, in their dying speeches, spoke of their duty to obey their Master and their Father. In the case of the regicides, such language was used to refer not to the King of England but rather to God, the King of Kings. God acted simultaneously as a master, a husband and a father. The patriarchal order they described was not earthly but divine.

It was God who was to act as a patriarch to the regicides families after their deaths. John Carew told his wife, "I resigne thee up to Jesus Christ to be thee Husband, to whom also I am going to be married in glory this day." 96 In a last conversation with his family John Cook referred to Jeremiah 49:11, in which God tells the inhabitants of Dedan: "Leave thy fatherless children, I will preserve them

93 John Milton, The tenure of kings and magistrates (London,1649), 10, 15.

${ }_{94}$ Cook, King Charls his case, 12.

95 J. G. Muddiman, Trial of King Charles the First (Edinburgh, 1928), 82.

96 W. S. A compleat collection, 53. 
alive; and let thy widows trust in me." Later, in his last dying speech John Cook asked that Isaiah 54:4-5, 10 be remembered to his wife and child. In verse five of this passage it is written: "For thy Maker is thine husband." Carew and Cook both exhorted their wives - soon to be widows - to take God as a husband and to put their unrestrained trust in him. Axtel similarly told his daughter that "he had left Jesus Christ an Executor in trust of her" and recommended that she "get an interst in Christ, and keep close to him, he will be a better Father to thee then I." 97 After their deaths, God was to be a husband to their widows and a father to their children. In believing this they did not differ from royalists who also believed that God was the ultimate patriarch. 98 However, unlike royalists, regicides were content with having God as sole patriarch seeking no earthly intermediaries to replace them. Indeed, such an attitude was necessary to justify the regicide.

This does not mean, however, that regicides believed they had no patriarchal duties. They understood their primary responsibility as providing religious instruction. J. Sears McGee has argued that Puritans, while they believed in the importance of living in a state of Christian harmony, also believed that this state could be achieved by even the most unregenerate person. 99 Therefore, Puritans' acts of charity tended to target the soul

97 W. S. A compleat collection, 165, 163.

98 Before his execution Lord Capel told his family: "God will be unto thee better than a husband and to my children better than a father"; see Howell, $A$ Complete Collection of State Trials, Vol. IV, 1231

99 J. Sears McGee The Godly Man in Stuart England : Anglicans Puritans, and the Two Tables, 1620-1670 (New Haven, 1976), 193 
(especially the souls of their co-religionist). They saw it as their duty to "to do all [they could] to help [their] fellow saints stay on the narrow path which leads to heaven."100 But such an attitude was not exclusively Puritan; Theodore Beza, one of John Calvin's disciples and the author of the influential Tabula praedestinationis, believed that predestination should be preached. In particular, he believed that in teaching reprobation the elect would learn to "hold God in greater fear and awe, and in learning that it is not in the power of every man to repent, would become more receptive to the special gift of faith." ${ }^{101}$ In accordance with these beliefs, the regicides (who were majoritarily puritans) provided lessons for the crowds who gathered to see them in prison and at their execution. John Carew tried to instil in all the glories of immortality and eternal happiness while Hugh Peter preached in jail on the dangers of despondency."102

Most of the regicides' instruction, however, was aimed at their friends and family who would, most likely, have been members of their godly community. They wished their families not to mourn their death but rather to trust in God's grace. Daniel Axtel told his daughter: "Where hast thou been all this while? I thought thou hadst been ashamed of my Chains, but they that will not bear the cross, shall not wear the Crown." 103 John Cook desired his wife "not to withhold him by an unwillingnasse to part with

100 McGee The Godly Man in Stuart England, 194

101 Peter White, Predestination, Policy and Polemic Conflict and Consensus in the English Church from the Reformation to the Civil War (Cambridge, 2002), 15

102 The speeches and prayers of some of the late King's judges, 74, 58-59

103 W. S. A compleat collection of the lives, 164 
him." After a pause, she accepted his wish. But at the last moment she began to cry and attempted to hold him back, to which he answered, "O doe not hinder me from going to Jesus Christ."104 It was an honour that God had chosen them to suffer for his cause. It was, therefore, considered an affront to God to mourn their deaths. ${ }^{105}$

Not everyone, however, believed in the regicides' election and martyrdom. Those who believed them to be traitors questioned their competence as patriarchs. W.S., the compiler of A Compleat collection of the lives, speeches, private passages, letters and prayers of these persons lately executed, accused John Cook of besmirching his family's reputation. He claimed that Cook "[left] the sad names of Traytor entayed to all posterity on his neglected Family."106 Not only did he dishonour his family in death he also neglected them in life. Similarly, after his trial, three ministers tried to encourage Harrison to repent. They charged him with five offences; the fourth of these charges was that he was "loose in Family duties, and the Observation of the Lords day." 107 Harrison refused to personally answer this charge and asked his servant to

104 The speeches and prayers of some of the late King's judges, 28

105 This was a characteristic of puritan piety and was not simply restricted to the regicides. Nehemiah Wallington, a puritan artisan, wrote in his diary that "great is the grief of an husband that loseth a kind and virtuous wife, and who can express the sorrow of a father or mother for the death of their dear and only child. But yet the sorrow in the world is not like the sorrow and grief of heart for sin." Despite this assertion Wallingford became inconsolable after the death of his daughter, Elizabeth. Finally his wife, Grace, told him "Husband, I am persuaded you offend God in grieving for this child so much [...] it is your daughter's wedding day and will you grieve to see your daughter go home to her husband Jesus Christ."; see Paul Seaver, Wallington's World : A Puritan Artisan in Seventeenth-Century London (Stanford, 1985), 85, 87 106 W. S. A compleat collection, 78.

107 Ibid., 8. 
speak for him. His servant stated that "those reports were very false, for his Master was a man in a manner wholly devoted to Religious Exercise [...] to the great comfort and consolation of his whole Family." 108 Whether or not the charge was true, it was clear that rumours of his incompetence as a patriarch were circulating. In questioning his actions as head of household his enemies were questioning his righteousness.

Those who opposed the regicides also criticised the actions that had brought them to the scaffold.

Rex est Patria Pater, the Father of his Country; and sure the better the Father is, the greater is the children loss; Mr. Scroopes children were seen weeping for their Father were comforted by a Friend. But when England lost a Father, and by his means too with others joined in the hellish Design, we the poor Subjects and Children of our Murdered Prince and Father, had not Comforter."109

It is not Scrope's actions as a father that were being criticised but his actions as a son. The implication was that he was guilty of parricide. He had conspired to destroy the kingdom's stability by dismantling the patriarchal order. He was, by reason of his crime, an unnatural son. Therefore, his children's loss was less than that of England and his guilt should make the audience indifferent to his suffering.

108 Ibid., 10.

109 Ibid., 134.

Past Imperfect 15 [2009] | (C) | ISSN 1711-053X | eISSN 1718-4487 
In 1649, parliament was also accused of destroying England's familial fabric. Its crimes included:

Killing the Father, carelesse of th'Infant

Making poore Widowes comfortlesse abroad

To Wander with their Children t'seek aboad

In forraigne Lands, being bereft of goods,

Lands, houses, rent yes and their Husbands bloods

Spilt by base Traytours to inebriate

Their thirsty soules... ${ }^{110}$

The Parliament - now led by the regicides - was guilty not only of the King's death but of the war and its consequences: death, widowhood and the fatherless children. They had no regard for familial bonds.

In many ways these criticisms are similar to those levied against the royalists by the parliamentarians. Each accused the other of creating chaos and disregarding the kingdom's familial fabric. This demonstrates a common concern for the patriarchal order. And yet there were significant differences that distinguished the two camps' patriarchal models. Royalists believed in earthly intermediaries while regicides preferred a direct connection to their divine patriarch. An interesting parallel can be drawn between these patriarchal models and royalist Episcopalianism on the one hand and

${ }^{110}$ A mournfull elegy upon the three renowned vvorthies Duke Hamilton, the Earle of Holland, and the ever to be honoured Lord Capel, who were tyranically murthered by a usurped illegall power of the wicked court of injustice, and pretended Parliament, upon Friday, the 9. of March, 1649. In the Palace-yard before Westminster-Hall-Gate. (London, 1649), 1. 
parliamentarian Presbyterianism or Congregationalism on the other. However, these similarities should not be over drawn. Not all royalist were Episcopalians and not all Presbyterians and Congregationalists were parliamentarians. The Duke of Hamilton is a case in point. He was a Presbyterian but also a Royalist who wished his brother to become a father to his children after his death. Still, each camp's respective discourse on religion and patriarchy may have influenced the way authors chose to portray him.

During the Civil Wars, the traditional family unit was perturbed; fatalities, exiles, imprisonments and competing loyalties all contributed to this disruption. Each camp invoked a patriarchal mandate and portrayed themselves as the defenders of a sacred familial and societal order. Their godly cause aimed to reinstate stability in the chaotic kingdoms of Britain. This could be achieved by behaving righteously and by alleviating God's wrath by eliminating those threatening true religion. By contrast, the enemy was portrayed as disregarding proper domestic governance and, by extension threatening social stability. An unsophisticated dichotomy distinguished the good and godly, who stood for the family, from the bad and sinful, who worked towards its destruction.

While there general consensus existed about the sacredness of patriarchal authority, the issue of if and how this authority translated into political obligation was a source of violent disagreement. Each camp, in justifying the righteousness of its own cause, laboriously invoked the legitimising language of patriarchy. Royalists used their 
domestic patriarchal model to uphold their political philosophy. Since the responsibilities of a father were likened to those of a ruler, a successful family life was offered as proof of an ability to govern. Conversely, regicides in their last moments were most concerned by that which is eternal. Congruently, the patriarchal order they described was divine. Regicides sought to become their divine father's passive instruments and instructed their families to emulate them in this. As patriarchs, they saw it as their responsibility to provide religious instructions and preserve the spiritual wellbeing of their families and co-religionists. 


\section{Bibliography}

Primary Sources

Burnet, Gilbert, The memoires of the lives and actions of James and William, Dukes of Hamilton and Castleherald, \&c. (London, 1677)

The chiefe heads of Mr. John Sares speech and other passages at the time of his execution at West-Chester; he being the portliest man the three kingdomes afforded, whose coffin was two yards and a halfe in length, yet too short to containe his corps; he suffered the 20th day of October (London, 1652)

Christus dei, the Lords annoynted, (Oxford, 1642)

Clarendon, Edward Hyde, Earl of, Memoirs of Kings Charles I and the loyalists who suffered in his cause; chiefly extracted from Lord Clarendon's History of the rebellion (London, 1795)

Cook, John, King Charls his case: or, An appeal to all rational men, concerning his tryal at the High Court of Iustice (London, 1649)

The Dying Speeches and Behaviour of the State Prisoners That have been Executed the last 300 years with their several characters from the best historian as Cambden, Spotswood, Clarendon, Sprat, Burnet \&c. (London, 1720) 
England's black tribunall set forth in the triall of K. Charles I at a High Court of Justice at Westminster-Hall (London, 1660)

Eikon Basilike: The Pourtrature of His Sacred Majestie in His Solitudes and Sufferings. With a perfect Copy of Prayers used by his Majesty in the time of his sufferings. Delivered to Dr. Juson Bishop of London, immediately before his Beath (London, 1649)

Hardy, Thomas, Love and Fear: The inseperable Twins of Blest Matrimony (London, 1653)

Howell, Thomas Bayly and William Cobbett, David Jardine, A Complete Collection of State Trials and Proceedings for High Treason and Other Crimes and Misdemeanors: From the Earliest Period to the Year 1783 (London, 1816), Vol. III

Howell, Thomas Bayly and William Cobbett, David Jardine, A Complete Collection of State Trials and Proceedings for High Treason and Other Crimes and Misdemeanors: From the Earliest Period to the Year 1783 (London, 1816), Vol. IV

The Kings cabinet opened: or, Certain packets of secret letters \& papers, written with the Kings own hand, and taken in his cabinet at Nasby-Field, June 14. 1645 (London, 1645) A mournfull elegy upon the three renowned vvorthies Duke Hamilton, the Earle of Holland, and the ever to be honoured Lord Capel, who were tyranically murthered by a usurped illegall power of the wicked court of injustice, and pretended 
Parliament, upon Friday, the 9. of March, 1649. In the Palaceyard before Westminster-Hall-Gate (London, 1649)

Nedham, Marchamont, Digitus Dei: or, God's justice upon treachery and treason; exemplifyed in the life and death of the late James Duke of Hamilton. Being an exact relation of his traiterous practises since the year, 1630 (London, 1649)

The several speeches of Duke Hamilton Earl of Cambridge, Henry Earl of Holland, and Arthur Lord Capel, upon the scaffold immediately before their execution, on Friday the 9. of March (London, 1649)

Sibbald, James, The maner of the beheading of Duke Hambleton, the Earl of Holland and the Lord Capell in the Pallace-Yard at Westminster on Friday the 9th of March, 1648, with the substance of their severall speeches upon the scaffold immediately before they were beheaded (London, 1648)

The speeches and prayers of John Barkstead, John Okey, and Miles Corbet together with severa[l] passages at the time of their execution at Tyiburn [sic], the nineteenth of April, 1662, with some due and sober animadversions of the said speeches (London, 1662)

The speeches and prayers of some of the late King's judges, viz. Major General Harison [and five others] ... Together with severall occasionall speeches and passages in their imprisonment till they came to the place of execution. 
Faithfully and impartially collected for further satisfaction (London, 1660)

Strafford, Thomas Wentworth, Earl of, A letter sent from the Earle of Strafford to his Lady in Ireland a little before his death May 11. 1641 (London, 1641)

W. S. A compleat collection of the lives, speeches, private passages, letters and prayers of those persons lately executed viz. (London, 1661)

William, Thomas, Christian and Conjugal Counsell (London, 1661)

Secondary Sources

Braddick, Michael, State Formation in Early Modern England, c. 1550-1700 (Cambridge, 2000)

Bossy, John Christianity in the West (Oxford, 1985)

Capp, Bernard, When Gossips Meet: Women, Family, and Neighbourhood in Early Modern England (Oxford, 2003)

Collinson, Patrick, The Religion of Protestants: The Church in English Society 1559-1625 (Oxford, 1982)

Crawford, Patricia, "The Challenge to Patriarchalism: How did the Revolution affect Women?" in John Morrill (ed)., Revolution and Restoration England in the 1650s (London, 1992).

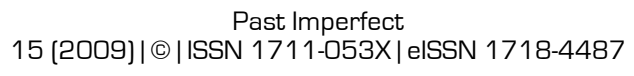


de Groot, Jerome. Royalist Identities (New York, 2004).

Freeman, Thomas S. “Imitatio Christi with a Vengeance': The Politicisation of Martyrdom in Early-Modern England" in Thomas S. Freeman and Thomas F. Mayer (eds.) Martyrs and Martyrdom in England, c. 1400-1700. (Rochester, 2007).

Gowing, Laura, Common Bodies: women, touch and power in seventeenth-century England (New Haven, 2003)

Gregory, Brad, Salvation at Stake: Christian Martyrdom in Early Modern Europe (Cambridge, 1999)

Jenkinson, Matthew T., "A New Author for the 'observation' in Rebels no Saints (1661)" in Notes and Queries (September 2005).

Lacey, Andrew, The Cult of King Charles the Martyr (Rochester, 2003)

Lacey, Andrew, "'Charles the First, and Christ the Second': The Creation of a Political Martyr" in Thomas S. Freeman and Thomas F. Mayer (eds), Martyrs and Martyrdom in England, c. 1400-1700. (Rochester, 2007). Lake, Peter and Michael Questier "Agency, Appropriation and Rhetoric under the Gallows: Puritans, Romanists and the State in Early Modern England" in Past and Present, No. 153 (Nov., 1996). 
Marshall, Peter, Reformation England, 1480-1642 (London, 2003)

McGee, J. Sears, The Godly Man in Stuart England:: Anglicans Puritans, and the Two Tables, 1620-1670 (New Haven, 1976)

McKenzie, Andrea “Author's Response of James Sharpe review of Tyburn's Martyrs: Execution in England 16751775, Andrea McKenzie" (review no. 677), Online (www.history.ac.uk/reviews/paper/sharperesp.html). Accessed on July 5, 2008.

McKenzie, Andrea, Tyburn's Martyrs: Executions in England 1675-1775 (London, 2007)

Muddiman, J. G., Trial of King Charles the First (Edinburgh, 1928)

Piroyansky, Danna. “'Thus may a man be a martyr': The Notion, Language and Experiences of Martyrdom in LateMedieval England" in Thomas S. Freeman and Thomas F. Mayer (eds.), Martyrs and Martyrdom in England, c. 14001700. (Rochester, 2007).

Pollock, Linda A. "Rethinking Patriarchy and the family in seventeenth-century England," in Journal of Family History (1998). 
Schochet, Gordon J., Patriarchalism in Political Thought (Oxford, 1975)

Seaver, Paul, Wallington's World:: A Puritan Artisan in Seventeenth-Century London (Stanford, 1985)

Sharpe, J. A., “'Last Dying Speeches': Religion, Ideology and |266

Public Execution in Seventeenth-Century in England" in Past and Present, No. 107 (May, 1985).

Shepard, Alexandra, Meanings of manhood in early modern England (Oxford, 2003)

Sommerville, J.P., Royalist and Patriots (London, 1999)

Underdown, David "The Taming of the Scold: the Enforcement of Patriarchal Authority in Early Modern England" in A. Fletcher and J. Stevenson (eds)., Order and Disorder in Early Modern England (Cambridge, 1985).

Wrightson, Keith "The Politics of the Parish in Early Modern England" in Paul Griffiths, Adam Fox and Steve Hindle (eds.), The Experience of Authority in Early Modern England by (New York, 1996). 